\title{
Anterior Choroidal Artery Occlusions: Clinical and Laboratory Features
}

\author{
Anterior Koroidal Arter Oklüzyonları: Klinik ve Laboratuvar Özellikleri
}

Lale Gündoğdu Çelebi, Münevver Gökyiğit, Reyyan Ezer, Özge Kiremitçi, Hülya Ertaşoğlu Toydemir, Nihan Parasız

Şişli Etfal Training and Research Hospital, Clinic of Neurology, Istanbul, Turkey

\section{Summary}

Objective: It is very well known that the anterior choroidal artery (AChA) irrigation area has a high incidence rate for infractions and that their clinical features vary drasticaly. We aimed to investigate the clinical characteristics of the patients with infacrts whose lesions are confined to the irrigation areas of AChA.

Materials and Methods: The patient group consisted of people who had lesions confined to AChA irrigation areas as shown in magnetic resonance imaging. In this study, 41 patients were included. People who had lesions in addition to the AChA area, lesions extending to the areas of other arteries, those with other lesions, those with a history of ischemic attack that is not associated with an AChA area infact, those with residual neurological symptoms as a result of a past brain vascular disease and/or people with past lesions that might cause neurological deficits were excluded from the study. When deciding if the lesion resides within AChA irrigation area, the typical pattern outlining thalamus and medial globus pallidus created by lesions involving the deep branch is taken into consideration. As for the surface branch, lesions that start from amygdala and hippocampus and extend to lateral ventricle posterior horn adjacency in a way that is incompatible with lenticulostriate arteries occlusions are taken into consideration.

Results: Hypertension was the most common risk factor with a significantly high difference. Except for 1 patient, all patients showed pure motor and sensorimotor stroke findings. Those with small vessel disease according to TOAST etiological classification were under higher risk compared to other etiologies. When risk factors were compared between etiological groups, those with hypertension and hyperlipidemia was higher for small vessel disease, and atrial fibrillation (AF) was

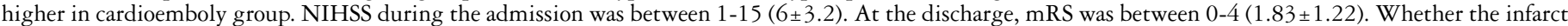
area was within the irrigation areas of a branch or all the branches of AChA did not have additional significance for risk factors, etiology and prognosis.

Conclusion: It is possible to detect the ischemic lesions in the AChA irrigation areas with magnetic resonance imaging. Ischemic lesions in the typical locations for AChA are seen in homogenous patient groups who show similarities in risk factors, etiology, and prognosis. Identification of these lesions carries importance in terms of prognosis and directing the treatment. (Turkish Journal of Neurology 2014; 20:105-111)

Key Words: Anterior choroidal artery, Lacunar syndrome, OCSP clinical classification, etiologic classification of ischemic stroke, small vessel disease

Conflict of interest: The authors reported no conflict of interest related to this article.

\section{Özet}

Amaç: Anterior koroidal arter (AChA) sulama alanında enfarkt sıklı̆̆ı ve enfarktların klinik özelliklerinin çok değişken olduğu klasik bir bilgidir. Çalışmamızda, lezyonu AChA sulama alanına sınırlı enfarktı olan hastaların klinik ve laboratuvar özelliklerinin belirlenmesi amaçlanmıştır.

Gereç ve Yöntem: Hasta grubu, manyetik rezonans görüntülemelerinde, AChA alanına sınırlı lezyonu olan hastalar seçilerek oluşturuldu. Çalışmaya 41 hasta dahil edildi. Akut lezyonu AChA alanına ek olarak, diğer arterlerin alanlarına da yayılan hastalar, ek lezyonu olanlar, AChA alanında enfarkt ile iliskilendirilemeyen geçici iskemik atak tanımlananlar, başvuru öncesinde geçirilmiş beyin damar hastalığı nedeniyle sekel nörolojik bulgusu olanlar ve/veya nörolojik defisit yapabilecek eski lezyonu görülenler dışlandı. Lezyonun AChA sulama alanında olduğuna karar verilirken, derin dalın sulama alanı olan talamus lateralinde talamusun sınırını çizen ve medial globus pallidusu da tutan lezyonun oluşturduğu tipik görüntü dikkate alındı. Yüzeyel dal için ise lentikülo-striat arterlerin oklüzyonlarında görülmeyen şekilde amigdala ve hippokampustan başlayıp lateral ventrikül posterior horn komşuluğuna kadar çıkan lezyon varlığı dikkate alındı.

Bulgular: Hipertansiyon ileri derecede anlamlı fark ile en yüksek oranda rastlanan değiştirilebilir risk faktörüydü. Bir hasta dışında tüm hastaların muayenelerinde pür motor veya sensorimotor inme bulguları mevcuttu. TOAST etiyolojik sınıflamasına göre küçük damar hastalığı olanlar, diğer etiyolojilere oranla anlamlı olarak yüksek orandaydı. Etiyolojik gruplarda risk faktörleri karşılaştırıldı ğında, hipertansiyon ve hiperlipidemi küçük damar hastalı̆̆ ise kardioemboli grubunda anlamlı derecede yüksekti. Hastaların giriş NIHSS 1-15 arasındaydı $(6 \pm 3,2)$. Taburculuklarında mRS $0-4$ arasındaydı $(1,83 \pm 1,22)$. Enfarkt alanının, AChA dallarından birinin veya tamamının sulama alanında olması, gerek risk faktörleri, gerekse etiyoloji ve prognoz açısından fark göstermiyordu. Sonuç: Anterior koroidal arter sulama alanındaki iskemik lezyonların, MR görüntüleme yöntemleri ile tanınması mümkündür. Anterior koroidal arter için tipik lokalizasyondaki iskemik lezyonlar, risk faktörleri, etiyoloji ve prognoz açısından benzer özellikler gösteren homojen hasta gruplarında görülmektedir. Bu lezyonların tanınması, prognoz ve tedavi belirleme açısından önem taşımaktadır. (Türk Nöroloji Dergisi 2014; 20:105-111)

Anahtar Kelimeler: Anterior koroidal arter, Laküner sendrom, OCSP klinik sınıflama, TOAST etiyolojik sınıflama, küçük damar hastalı̆̆

Çıkar çatışması: Yazarlar bu makale ile ilgili olarak herhangi bir çıkar çatışması bildirmemişlerdir. 


\section{Introduction}

Anterior choroidal artery (AChA) originates from supraclinoid segment of internal carotid artery and it is often the first branch of internal carotid artery. However, AChA may also originate from middle cerebral artery or posterior communicating artery $(1,2)$. Anatomical studies show that the deep branch of AChA irrigates two thirds of the posterior leg of internal capsule, medial globus pallidus, optic and auditory radiations, tail section of caudate nucleus; its superficial irrigates uncus, head segment of hippocampus, amygdala, piriform cortex and lateral section of lateral geniculate nucleus, with some variation being possible in this list of areas (3). First defined by Kolisko in 1891 and Foix et al. in 1925, the classic triad of AChA infarcts that is hemiplegia, hemianesthesia and homonym hemianopsia, has been confirmed in the limited number of studies in the following years $(1,3,4)$. The prevalence of ischemic lesions confined to AChA irrigation areas among other supratentorial ischemic lesions have been reported to be between $3 \%$ and $30 \%$ in different studies $(3,5)$. Studies investigating the irrigation areas of AChA and ischemic lesions in these areas reported that both the areas and the lesion frequencies on these areas, as well as the clinical manifestations of such lesions show great variance, and thus reinforced the notion as textbook knowledge that AChA occlusions cannot be delineated (6). After the prevalent use of magnetic resonance imaging (MRI), more studies showing AChA infarcts have been published (2,3). Among the ischemic stroke patients being followed in our clinic, those who had lesions confined to regions that could be described as AChA irrigation areas in MRI have drawn our attention.

Our study aims to identify the clinical properties of cases who have ischemic lesions confined to AChA and the distribution of these lesions.

\section{Mterials and Method}

In this retrospective study, 1216 patient files in Şişli Etfal Training and Research Hospital between the dates January 2010 and December 2012 with the diagnosis of acute ischemic stroke have been reviewed. Patients who had ischemic lesions in AChA regions were determined. Ethical approval, number 387, was obtained from Ethical Board of Şişli Etfal Training and Research Hospital on the date 05.14.2013.

Patient group were created by selecting patients with lesions confined to deep and/or superficial branch areas (AChAD; AChAS). The patients whose acute lesions extend to areas of other arteries in addition to AChA, those with additional lesions, those with transient ischemic attacks that cannot be associated with AChA infacts, those with residual neurological findings due to a previous vascular brain disease and/or with previous lesions that could cause neurological deficits were excluded from the study. If the patient suffered from a vascular brain disease other than those, however, it was recorded in the data. One patient who came to ER with lung infection, high fever, breathing difficulty, consciousness disorders among other conditions was excluded from the study even though their lesion was consistent with AChA area, for the reason that their clinical symptoms were dominated by systemic disease findings.

All patients except one had diffusion and apparent diffusion coefficient (ADC) sequences and other cranial MRI studies conducted at the time of their first ER visit. One patient had a metal heart prosthetic which required cranial computerized tomography (CT) to detect the lesion. All cranial MRI studies were conducted using a $1.5 \mathrm{~T}$ magnet (Excite 2.0, GE Medical Systems) and standard acquisition methods. When determining if a lesion resides in AChA irrigation area, the typical look outlining thalamus from the thalamus lateral also involving globus pallidus was taken into consideration for deep branch's irrigation area (Figure 1). For superficial branch, the presence of a lesion in the area starting from amygdala and hippocampus ascending to lateral ventricle posterior horn adjacency, excluding the outlook seen in lenticulo-striate artery occlusions (Figure 1) was taken into consideration. Forty one patients were determined as the patient group using these criteria. The patient group was further divided into 2 subgroups as those with infarcts on only deep or only superficial branch areas of AChA ("AChAD or AChAS"), and those with involvement on both branches at the same time (“AChAD+AChAS").

Ages, sex, vascular risk factors such as hypertension, diabetes mellitus, hyperlipidemia, heart disease, history of stroke, atrial fibrillation (AF), smoking and alcohol use of the patients were recorded. Reasons for visitation for all patients, their symptoms, neurological findings at the time of admission and the drugs they used were investigated. Routine biochemical studies, serological tests (VDRL, TPHA), electrocardiogram (ECG), transthoracic echocardiogram and/or transesophageal echocardiogram, bilateral carotid vertebral artery Doppler ultrasonography, cranial MR angiography were evaluated. For young patients (age <45: 3 patients) we made sure that vasculitis studies were conducted. In one case, Doppler ultrasonography was not performed but the presence of symptomatic or asymptomatic constriction was determined based on cervical CT-angiography findings. The clinical statuses of the patients were determined according to Oxfordshire Community Stroke Project (OCSP) classification, and etiological classification was determined using Trial of ORG in Acute Stroke Treatment (TOAST) criteria $(7,8)$. For the prognosis evaluation, we used National Institute of Health Stroke Scale (NIHSS) and modified Rankin Scale (mRS) were used for their admission and discharge (approximately on the 10th day) $(9,10)$. NIHSS score $<8$ had $\mathrm{mRS}$ score 1 ; NIHSS score between $8-14$ had mRS score 1 or 2 ; NIHSS score $>14$ had mRS score $1-3$ were determined as patients with good prognosis. Others (NIHSS score $>14$ and mRS score 4-6) were determined as bad prognosis $(9,10)$.

For statistical analyses, SPSS 16.0 for Windows Evaluation Version was used. The two groups "AChAD or AChAD" and "AChAD+AChAD" were compared for etiology, risk factors and prognosis using Chi-square (or Fisher test, when necessary).

\section{Results}

Among 1216 patients with ischemic stroke diagnosis, 41 patients had lesions on the AChA irrigation area. Twenty three of these 41 patients were male and 18 of them were female $(56.1 \%$ and $43.9 \%)$ between the ages 37 and $90(65.93+13.05)$. Their hospital stay lasted between 5 and 22 days $(11.15 \pm 3.95)$. Lesion was located on the left for 19 patients and right in 22. Twenty (48.8\%) patients had AChA-deep/superficial, 21 (51.2\%) patients had AChA-deep+superficial area infarcts and there 
were statistically significant difference in terms of lateralization $(\mathrm{p}=0.87)$ (Table 1$)$.

Changeable risk factors are shown on Tables 2 and 3. Hypertension significantly was the most frequently seen risk factor by a large margin $(\mathrm{p}<0.001)$. In 11 patients, AChA occlusion developed during prophylactic treatment: 8 of them during antiaggregant treatment and 3 of them during anticoagulant use.

All patients but one showed pure motor or sensory stroke symptoms (OCSP classification: "Lacunar syndrome"). One patient (OCSP classification: "partial anterior circulation syndrome") had head-eye deviation and homonymous hemianopsia in addition to hemiparesis and hemihypoesthesia. This patient with partial anterior circulation syndrome was in "AChAD+AChAS" group and the infarct site coincided with the entirety of the irrigation area of deep and superficial branches (Figure 2). However, the lesions of the patients in "AChAD+AChAS" group did not involve the whole irrigation area of AChA, even though they involved the areas of both branches (Figure 3). The distribution of the clinical conditions of 21 patients in "AChAD or AChAS" and "AChAD+AChAS" subgroups according to OCSP classification was the same.

The distribution of the entire patient group, and "AChAD or AChAS" and "AChAD+AChAS" subgroups according to TOAST etiological classification is given in Tables 4 and 5, and the risk factors of the entire patient group according to TOAST classification is given in Table 6. People with small vessel disease were significantly more common compared to other etiologies $(\mathrm{p}<0.001)$ (Table 4). For all TOAST classification groups, "AChAD or AChAS" and "AChAD+AChAS" patients were equal (Table 5). When the risk factors for etiological groups were compared, hypertension and hyperlipidemia was significantly more common in small vessel disease; atrial fibrillation (AF) was more common in cardioembolism group $(\mathrm{p}=0.035 ; \mathrm{p}=0.011 ; \mathrm{p}=0.005$ respectively). Results of laboratory and other studies that the etiology in TOAST classification is based on are shown in Table 7.

The entrance NIHSS scores of the participants were between $1-15$ (median $=6)$. In only one of the patients NIHSS score was $>14($ NIHSS $=15)$. This patient had partial anterior circulation syndrome and was in "AChAD+AChAS". In exit examinations, NIHSS scores for all patients were lower (between 0-12; median= 4). The decline in NIHSS scores between entrance and exit was found to be statistically significant $(p<0.001)$. One patient showed worsened clinical findings at the time of admittance. Repeated diffusion MRI study showed that the lesion got bigger but were still limited to AChA region (Figure $4 \mathrm{a}, \mathrm{b}$ ). Despite the worsening examination findings at the time of admittance, the symptoms improved before discharge. Table 8 shows NIHSS at entrance and exit for "AChAD or AChAS" and "AChAD+AChAS". During discharge mRS scores of the patients were between 0-4. For six patients, exit mRS score were above 3 , meaning $\mathrm{mRS}=4$.

\section{Discussion}

In our study, the ratio of patients whose ischemic lesions were confined to AChA irrigation area to the ischemic stroke group was found to be $3.4 \%$. The infarcts of AChA were first reported by Kolisko et al. in 1891 and Foix et al. in 1925 (1,3,4). Until 1983, there have been only 25 reported cases (1). After his date, two studies with $\mathrm{Ct}$ and a limited number of studies using newer
Table 1. Lateralization in "AChAD or AChAS" and AChAdeep+superficial occlusions*

\begin{tabular}{lccc}
\hline Lateralization & Localization & \multicolumn{2}{c}{ Total } \\
\hline & "AChAD or & "AChAD+AChAS"**** & \\
Right & 9 & 10 & 19 \\
Left & 11 & 11 & 22 \\
Total & 20 & 21 & 41 \\
\hline
\end{tabular}

*: $\mathrm{p}=0.87,{ }^{* *}:$ Anterior choroidal artery branch occlusion , ***: Anterior choroidal artery total occlusion

Table 2. Changeable risk factors for all patients

\begin{tabular}{lcc}
\hline Risk factors & $\mathbf{n}^{*}$ & $\%^{* *}$ \\
\hline Hypertension & 33 & 80.5 \\
Hyperlipidemia & 17 & 41.5 \\
Smoking & 16 & 39 \\
Diabetes mellitus & 15 & 36.6 \\
Heart disease & 8 & 19.5 \\
Atrial fibrillation & 8 & 19.5 \\
Past brain vascular disease & 7 & 17.1 \\
\hline ": Number of patients with risk factors, **: Ratio of the patients affected with \\
that risk factor to total number.
\end{tabular}

Table 3. Changeable risk factors for " "AChAD or AChAS” and "AChAD+AChAS" subgroups

\begin{tabular}{lcc}
\hline Risk factors & $\begin{array}{c}\mathrm{ACh}_{\mathrm{D}} \text { or } \\
\mathrm{ACh}_{\mathbf{Y}} \text { " (n) }\end{array}$ & $\begin{array}{c}\text { "ACh } \mathrm{A}_{\mathrm{D}^{+}} \\
\mathrm{ACh}_{\mathbf{Y}} \text { " (n) }\end{array}$ \\
\hline Hypertension & 17 & 16 \\
Hyperlipidemia & 9 & 8 \\
Smoking & 8 & 8 \\
Diabetes mellitus & 7 & 8 \\
Past brain vascular & 5 & 2 \\
disease & & \\
Heart disease & 4 & 4 \\
Atrial fibrillation & 3 & 5
\end{tabular}

Table 4. TOAST etiological classification

\begin{tabular}{lcc}
\hline Etiology & $\mathbf{n}$ & $\%^{*}$ \\
\hline $\begin{array}{l}\text { Large artery atherosclerosis (thrombosisor } \\
\text { embolism) }\end{array}$ & 3 & 7.3 \\
Cardioembolism & 5 & 12.2 \\
Small vessel disease & 20 & $48.8^{* *}$ \\
Other etiologies & 1 & 2.4 \\
Unknown (or multiple) etiologies & 12 & 29.3 \\
\hline $\begin{array}{l}\text { n: Number of patients, *: Ratio of the patients affected with that etiology to } \\
\text { total number, }{ }^{* *} \text { : Statistically significant difference from the etiologies found in } \\
\text { the group (p<0.001) }\end{array}$
\end{tabular}


Table 5. Etiologies in “AChAD or AChAS" and “AChAD+AChAS” occlusions

\begin{tabular}{|c|c|c|c|c|c|c|c|}
\hline \multirow[t]{2}{*}{ Etiology } & & & \multicolumn{5}{|c|}{ Lesion location } \\
\hline & & & \multicolumn{2}{|c|}{ "AChAD or $A C h A_{Y}$ " } & \multicolumn{2}{|c|}{ “AChAD + AChAY" } & Total \\
\hline \multicolumn{3}{|l|}{ Large artery atherosclerosis } & \multicolumn{2}{|c|}{2} & \multicolumn{2}{|c|}{1} & 3 \\
\hline \multicolumn{3}{|l|}{ Small artery atherosclerosis } & \multicolumn{2}{|c|}{10} & \multicolumn{2}{|c|}{10} & 20 \\
\hline \multicolumn{3}{|l|}{ Other known etiologies } & \multicolumn{2}{|c|}{0} & \multicolumn{2}{|c|}{1} & 1 \\
\hline \multicolumn{3}{|l|}{ Total } & \multicolumn{2}{|c|}{20} & \multicolumn{2}{|c|}{21} & 41 \\
\hline \multicolumn{8}{|c|}{ Table 6. Distributions of patient group risk factors over TOAST classification } \\
\hline Risk factor & Etiology & & & & & & Total \\
\hline Hypertension & Total & 3 & 5 & 20 & 1 & 12 & 41 \\
\hline \multirow[t]{4}{*}{ Hyperlipidemia } & Present & 0 & 0 & $13^{*}$ & 1 & 3 & 17 \\
\hline & Absent & 3 & 5 & 7 & 0 & 9 & 24 \\
\hline & Total & 3 & 5 & 20 & 1 & 12 & 41 \\
\hline & $\mathrm{AF}+* *$ & 0 & $3^{*}$ & 0 & 0 & 5 & 8 \\
\hline \multirow[t]{2}{*}{ ECG } & NSR & 3 & 2 & 20 & 1 & 7 & 33 \\
\hline & Total & 3 & 5 & 20 & 1 & 12 & 41 \\
\hline
\end{tabular}

*: Etiological group and risk factor according to TOAST classification that show statistically significant difference, $\mathrm{p}=0.035$ for hypertension, $\mathrm{p}=0.011$ for hyperlipidemia, $\mathrm{p}=0.005$ for atrial fibrillation, ${ }^{* *}$ : atrial fibrillation

Table 7. Etiological distribution of anterior choroidal artery patients according to clinical and laboratory findings

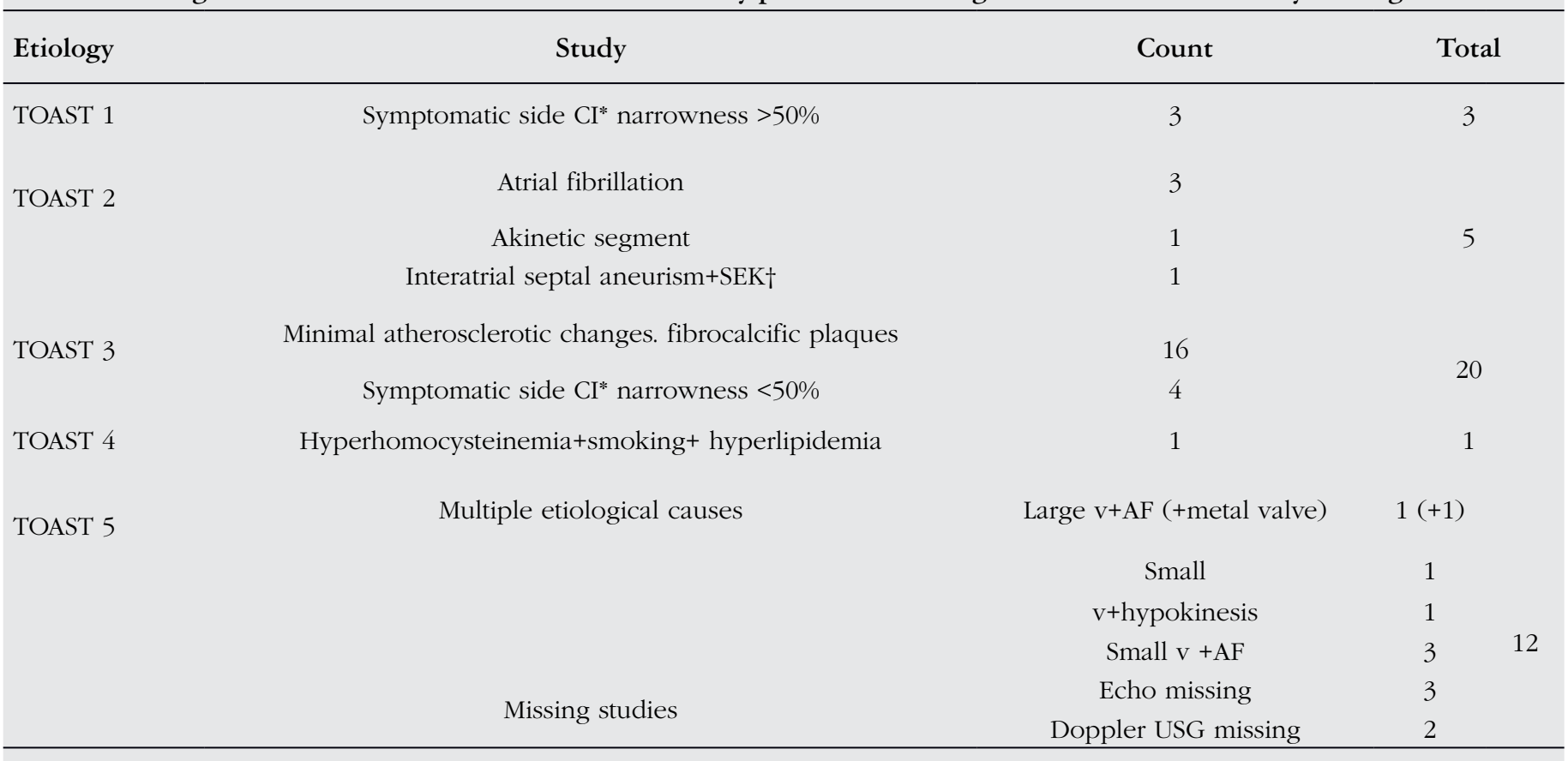

*Carotis interna, $†$ Spontaneous echo contrast 
Table 8. NIHSS scores of the patients

\begin{tabular}{|c|c|c|c|c|}
\hline \multirow[b]{2}{*}{ Descriptive statistics } & Entrance NIHSS & \multicolumn{3}{|c|}{ Exit NIHSS } \\
\hline & $\begin{array}{c}\text { “AChAD or AChAy" } \\
(n=20)\end{array}$ & $\begin{array}{c}\text { “AChAD + AChAy" } \\
(\mathrm{n}=21)\end{array}$ & $\begin{array}{c}\text { "AChAD or AChAy" } \\
(n=20)\end{array}$ & $\begin{array}{c}\text { “AChAD+AChAy" } \\
(\mathrm{n}=21)\end{array}$ \\
\hline Medyan & 5 & 7 & 3 & 5 \\
\hline Minimum & 1 & 3 & 0 & 0 \\
\hline Maksimum & 13 & 15 & 12 & 11 \\
\hline
\end{tabular}
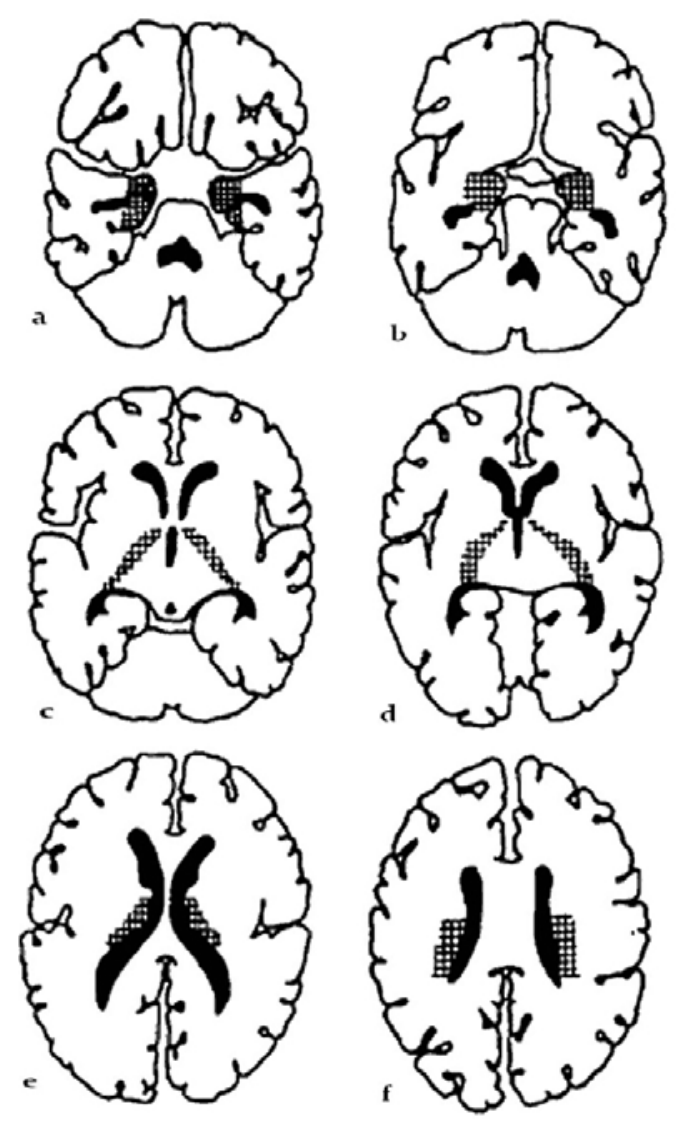

Figure 1. Anterior choroidal artery irrigation areas (highlighted). a, b) surface branch area; c-f) deep branch area (Adapted from Bruno A. Et al: Anterior choroidal artery territory infarction: a small vessel disease. Stroke 1989; 20:616-619)

imaging techniques suggested AChA infarcts as the second most common infarcts of the deep perforation of carotid system (1). The capability of the newer imaging techniques such as MR angiography in detecting AChA are still a matter of debate (11). This situation can be explained by the special anatomy of AChA and the rich anastomoses that it develops.

The frequency of ischemic lesions on the AChA irrigation area was reported as $2.9 \%$ by Sterbini et al. and $5.13 \%$ by Palomeras et al. $(3,12)$. Due to the fact that both studies had to exclude patients with systemic diseases or residual findings from older lesions, it is possible that the reported ratios can vary a little. Based on

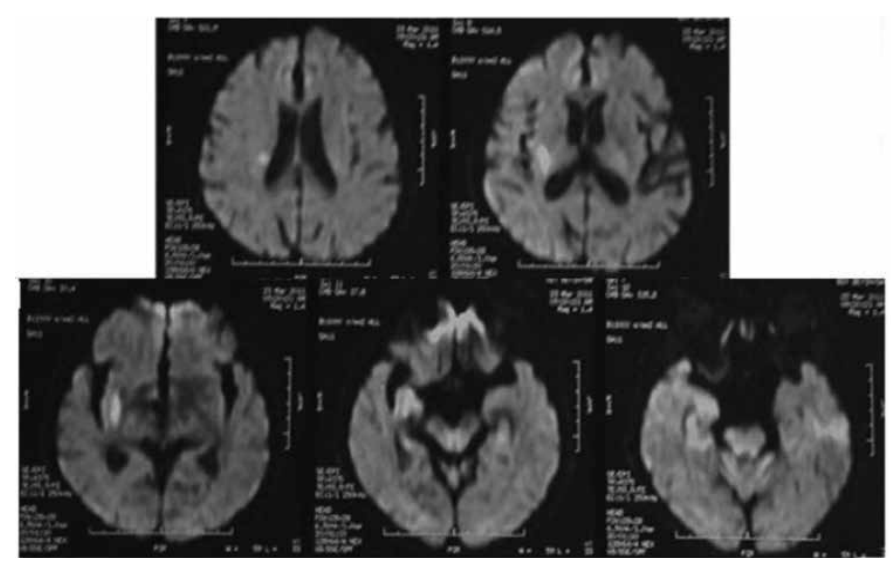

Figure 2. Anterior choroidal artery deep and superficial branch joint involvement, an infarct covering the entire irrigation area

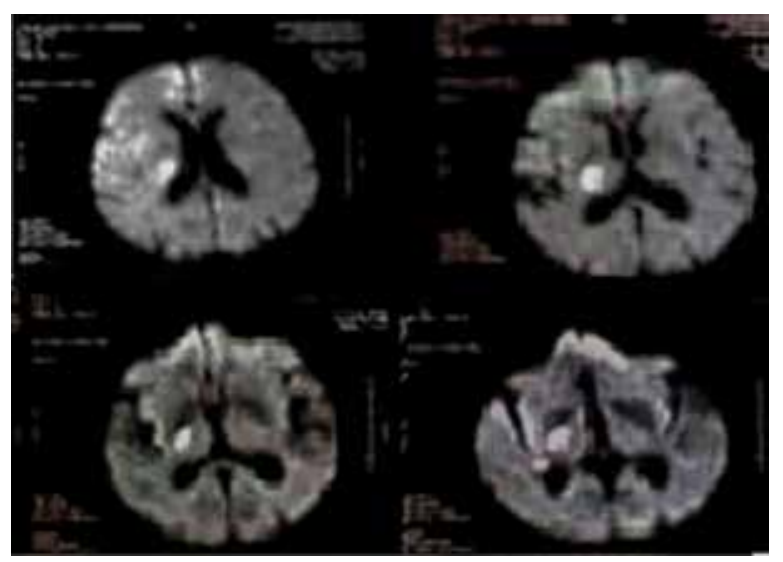

Figure 3. Anterior choroidal artery deep and superficial branches joint involvement, partial coverage of the irrigation area by the infarct

the literature, however, it is possible to say that the frequency of ischemic lesions on the AChA irrigation area is $3-5 \%$, much like it is confirmed by our study.

In our study, hypertension was significantly the most commonly seen risk factor. Atrial fibrillation and heart disease were less common. In a study by Bruno et al. using patients with AChA infarcts as shown by CT, it was found that, much like our study, the most important risk factor was hypertension and that carotid artery stenosis and potential cardiac embolism sources can be coincidental (13). Similarly in other studies, findings that could suggest cardiac embolism are much less common $(12,14,15)$. 

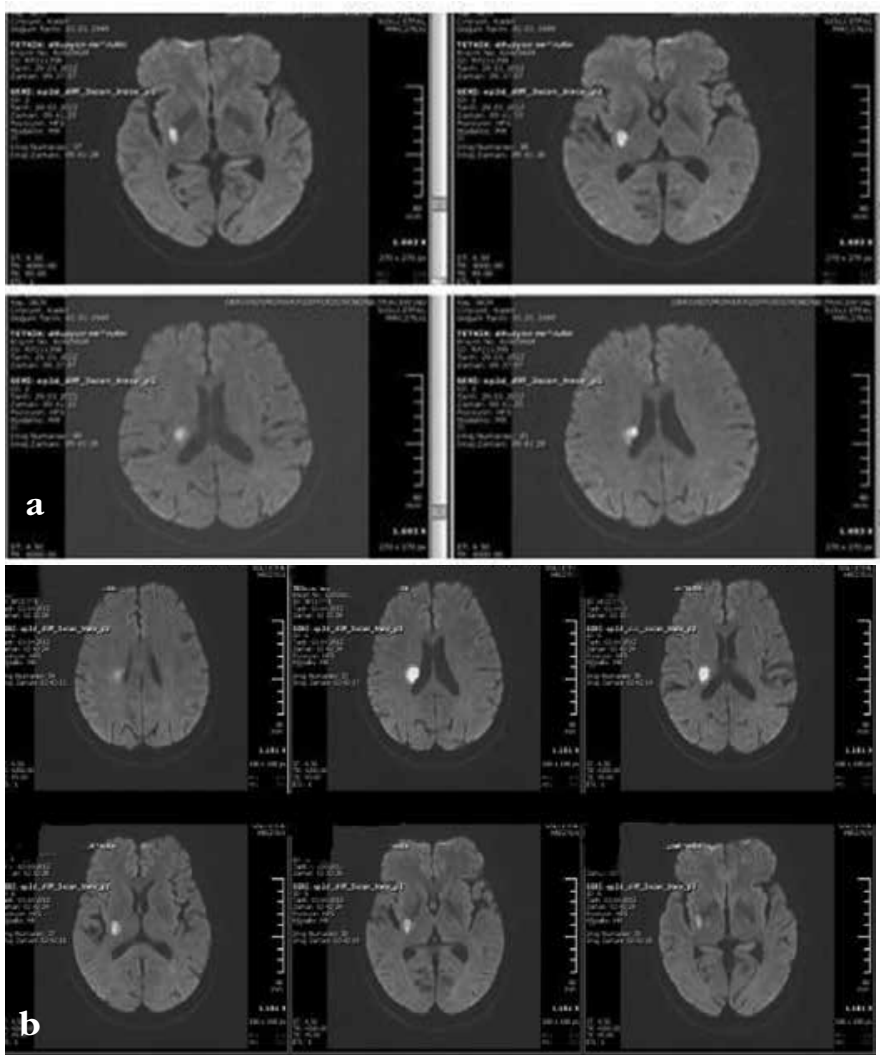

Figure 4. a) First imaging study of the patient upon admission; b) MRI study repeated after the clinical progression; enlarged lesion on anterior choroidal artery deep and superficial branches area

All but three of our patients showed pure motor or sensorymotor stroke findings. Much like in our study, the most common finding in AChA infarcts is hemiparesis. It can be at moderate or high severity. It is often accompanied by sensory symptoms but it may also present as pure motor disorder $(5,16)$.

The clinical picture of the AChA irrigation area ischemic lesions was first reported in 1891 as hemiplegia, hemianesthesia and homonymous hemianopia (1). After 1983, however, two CT studies showed the large diversity in AChA irrigation area infarcts and their clinical manifestations due to the entanglement of AChA and smaller arteries in that neighborhood $(6,14)$. With the advancement of newer techniques, AChA infarcts became more defined and partial clinical patterns such as lacunar syndrome was seen to be more common (1). Sensory symptoms occur due to the involvement of sensory pathways going through the posterior leg of internal capsule or the involvement of thalamus. In addition to the evidence of pure sensory findings in AChA infarct patient series, there are also studies suggesting that sensory findings are not seen in isolation but only in conjunction with motor findings $(5,16)$.

One of our patients had cortical findings (head-eye deviation and/or aphasia, homonymous hemianopia) in addition to hemiparesis and hemihyposthesia. The most commonly seen visual field disorders in AChA occlusions are homonymous hemianopia and upper quadrant defect (16). In our study, small vessel disease according to TOAST etiological classification was more common than other etiologies. When the risk factors of the etiological groups were compared, hypertension and hyperlipidemia was more frequently seen in people with small vessel disease and AF was more common in cardioembolism group. Among the reasons for AChA occlusions, the most emphasized one is small vessel disease. This mechanism is thought to be responsible especially for the dorsal leg of internal capsule and medial globus pallidus infarcts. If AChA infarcts reach to medial temporal lobe and if ipsilateral carotid artery disease (stenosis, atherosclerotic plaque) is detected, arteryto-artery embolism should be considered as the infarct mechanism $(1,16)$. Other causes such as cardioembolism and hyperviscosity have also received attention $(12,14,16,17)$. Helgason et al. reported potential cardiac embolism sources in 2 patients with AChA out of 11 (one AF, other ischemic cardiomyopathy), and they suggested small vessel occlusions as the most common cause of AChA irrigation area infarcts (15). Bruno et al. investigated the cause of infarcts in 31 patients with AChA infarcts and reported that those were caused by small vessel disorder with chronic hypertension being the most important risk factor. However, only half of the patients went through echocardiography to evaluate their carotid arteries (13). It is clear that different studies originating from different centers report very different results for AChA occlusions (18). The reason for this variation is probably the number of missing measurements and the lack of exclusion of patients whose lesions lay outside of AChA regions. The notion that small vessel disease is the leading cause of AChA infarctions, however, has gained traction and the most common risk factor has been accepted as hypertension much like in our study $(4,6,19)$.

In our study, we differentiated and evaluated the infarcts in "AChAD or AChAS" and "AChAD + AChAS" and arrived at the same conclusions with the anatomical studies and only one other non-anatomical study. In Palomeras et al. study as well, like in our study, there were no differences in etiological clinical classification between only deep branch occlusion, and deep and superficial branch involvement together (3).

Median NIHSS score at the time of entry was found to be 6 in out patient group while the exit score was found to be 4 . Exit NIHSS was lower for all patients and the mRS values were between $0-4$. Only $19.4 \%$ of our cases had $\mathrm{mRS}>3$. These findings suggested that AChA area lesions may have good prognosis. There is little information available on the prognosis and severity of deficit in patients with AChA area infarcts (20). Also in Palomeras et al. study, median NIHSS score was 3, and the mean score during discharge was 2 (3). In other studies that took $\mathrm{mRS}$ as the criterion, $31 \%$ of the cases required walking assistance (5).

In conclusion, it is possible to detect AChA irrigation area lesions with MRI methods. Ischemic lesions located in typical AChA areas can be seen in homogenous patient groups with similar risk factors, etiologies and prognoses. Recognition of such lesions carry importance in terms of prognosis and treatment planning.

\section{References}

1. Vuadens P, Bogousslavsky J.Anterior choroidal artery territorry infarcts.İn: Bogousslavsky J, Caplan LR. Stroke Syndromes. 2nd ed. New York: Cambridge University Press, 2001:451-460.

2. Ois A, Cuadrado-Godia AE, Solano A, Perich Alsina X, Roquer J. Acute ischemic stroke in anterior choroidal artery territory. J Neurol Sci 2009;281:8084. 
3. Palomeras E, Fossas P, Cano AT, Sanz P, Floriach M. Anterior choroidal artery infarction:a clinical, etiologic and prognostic study. Acta Neurol Scand 2008;118:42-47.

4. Pezzella FR, Vadala R. Anterior Choroidal Artery Territory İnfarction. İn: Paciaroni M, Agnelli G, Caso V, Bogousslavsky J (eds). Manifestations of Stroke. Front Neurol Neurosci. Basel Karger 2012;30:123-127.

5. Hupperts RM, Lodder J, Heuts-Van Raak EP, Kessels F. Infarcts in the anterior choroidal artery terrytorry. Anatomical distribution, clinical syndromes, presumed pathogenesis and early out come. Brain 1994;117:825-834.

6. Ropper AH, Brown RH. Adams and Victor's Principles of Neurology. 8th ed. New York: McGraw-Hill,2005.

7. Bamford J, Sandercock P, Dennis M, Burn J,Warlow C. Classification and natural history of clinically identifiable subtypes of cerebral infarction. Lancet 1991;337:1521-1526.

8. Adams HP, Bendixen BH, Kappelle LJ Biller J, Love BB, Gordon DL, Marsh EE 3rd. Classification of subtype of acute ischemic stroke. Deffinitions for use in a multicenter clinical trial.Stroke 1993;24:35-41.

9. Lyden P, Brott T, Tilley B Welch KM, Mascha EJ, Levine S, Haley EC, Grotta J, Marler J. NINDS TPA Stroke Study Group. İmproved reliability of the NIH Stroke Scale using video training. Stroke 1994;25:2220-2226.

10. Bonita R, Beaglehole R. Modification of Rankin Scale: recovery of motor function after stroke. Stroke 1988;19:1497-500.

11. Wiesmann M, Yousry I, Seelos KC, Yousry TA. Identification anf Anatomic Description of the Anterior Choroidal Artery by Use of 3D-TOF Source and 3CISS MR Imaging. AJNR Am J Neuroradiol 2001;22:305-310.
12. Paroni Sterbini GL, Agatiello LM, Stocchi A, Solivetti FM. CT of ischemic infarctions in the territory of the anterior choroidal artery: a review of 28 cases. AJNR Am J Neuroradiol 1987;8:229-232.

13. Bruno A, Graff-Radford NR, Biller J,Adams HP. Anterior choroidal artery territory infarction: a small vessel disease.Jr Stroke 1989;20:616-619.

14. Decroix JP, Graveleau Ph, Mason M, Cambier J. Infarction in the territory of the anterior choroidal artery. A clinical and computerized study of 16 cases. Brain 1986;109:1071-1085.

15. Helgason C, Caplan LR, Goodwin J, Hedges T 3rd. Anterior choroidal arteryterritory infarction. Report of cases and review.Arch Neurol 1986;43:681-686.

16. Kutluk K. Anterior Koroidal Arter Alan İnfarktları. İn: Kumral E.Santral Sinir Sisteminin Damarsal Hastalıkları.1.Baskı. Ankara: Ayrıntı Basımevi,2011:387-389.

17. Levy R, Duyckaerts C, Hauw JJ. Massive İnfarcts Involving the Territory of the Anterior Choroidal Artery and Cardioembolism. Stroke 1995;26:609-613.

18. Leys D, Mounier-Vehier F, Lavenu I, Rondepierre P, Pruvo JP. Anterior choroidal artery territory infarcts. Study of presumed mechanisms. Stroke 1994;25;837842 .

19. Sohn H, Kang DW, Kwon SU, Kim JS. Anterior choroidal artery territory infarction:lesions confined to versus beyond the internal capsule. Cerebrovasc. Dis 2013;35:228-234

20. Derfinger S, Fiebach JB, Böttger S, Habert RL, Audebert HJ. The progressive course of neurological symptoms in anterior choroidal artery infarcts. Journal of Stroke 2013;1747. 